\title{
Global Framework Agreements and Trade Unions as Monitoring Agents in Transnational Corporations
}

\author{
Rémi Bourguignon, Pierre Garaudel and Simon Porcher \\ IAE Paris I Panthéon-Sorbonne (Sorbonne Business School)
}

2019, forthcoming in Journal of Business Ethics

\begin{abstract}
In combining the micropolitics approach in international management, the industrial relations literature and business ethics, this article conceptualizes global framework agreements as an alliance between central CSR managers of transnational corporations and central actors within trade unions to monitor subsidiaries in the implementation of CSR policies. The empirical investigation, based on the qualitative analysis of 10 French multinational companies, confirms the relevance of such a conceptualization. It particularly shows that central CSR managers hope mobilizing the union network to increase their capacity to supervise subsidiaries. Over there, it helps understanding concrete mechanisms adopted to implement global framework agreements since, in some of the studied cases, the managerial and union channels are coordinated precisely to strengthen this capacity. It, then, highlights the procedural nature of policies regarding global framework agreements. Overall, this paper examines the conditions necessary for mobilization of the union network and suggests avenues for future research.
\end{abstract}

Keywords: Global Framework Agreement; Global union federation; Trade union network; Monitoring.

\section{Corresponding Author: Remi Bourguignon}

IAE - Université Paris 1 Panthéon Sorbonne

8 bis rue de la Croix Jarry

75013 Paris - France

Phone : 0033689904774

Email/ bourguignon.iae@ univ-paris1.fr 


\section{Introduction}

Global framework agreements (GFAs) are tools for the international regulation of work, social democracy or social dialogue (Hadwiger 2015; Lévesque et al. 2016; Niforou 2014; Papadakis 2008; Wills 2002). Because they are based on social dialogue, unlike more unilateral management approaches, these agreements foster hope in effective regulation whereas the limits of codes of conduct have been exposed (ILO 2016; Egels-Zandén and Hyllman 2007). However, recent studies have shown that the regulatory potential of GFAs is also reaching its limits (Williams et al. 2015), calling for additional research combining the fields of industrial relations and business ethics that is focused on their effectiveness.

GFAs are tools for implementing corporate social responsibility (CSR) policies in transnational companies (TNCs). GFAs are typically compared to codes of conduct, as they share the equivalent function of formalizing the TNCs' engagement towards business ethics. Their main difference is procedural: codes of conduct are unilaterally adopted by companies whereas GFAs result from collective bargaining with trade unions, and particularly with global union federations (GUF). Combining knowledge in international management, business ethics and industrial relations, the academic literature investigated these agreements to understand their characteristics and dynamics using distinct theoretical approaches. For example, in conceptualizing them as continuous bargaining outcomes, Egels-Zanden (2009) presents GFAs as an alternative to codes of conduct. Drawing on a detailed case study, he analyses GFAs as the result of stakeholder pressure embedded in a long-term continuous corporate-union relationship. Signing a GFA is then a constrained choice for management to retain the trusting corporate-union relationship. With such a conceptualization, Egels-Zanden (2009) calls for a refined understanding of stakeholder pressure. Fichter et al. (2011) propose an alternative conceptualization. In focusing on how transfers of more decent work practices are initiated rather than on why, the authors propose that GFAs are the fruit of a social partnership between management and trade unions. They are essentially mechanisms for mobilizing an external actor, i.e., the GUF, in the transfer of practices within TNCs.

The aim of our article is to reconcile these two conceptualizations by mobilizing the micropolitics analysis of organizations (Burns, 1961). The continuous bargaining conceptualization is partly challenged by the very collaborative form of the negotiation, which is highlighted in the literature (e.g. Niforou 2012). This collaborative nature of GFAs' negotiation process does not allow for an analysis essentially focused on stakeholder pressure. 
For its part, the conceptualization in terms of transfer of practices has the merit of reintroducing an organizational dimension but suffers from an overestimated homogeneity ascribed to certain actors, especially the headquarters' management or trade unions, who are reduced to the GUF. Beyond the question of whether we have to focus on pressure or partnership when analyzing GFAs, we can see that a critical debate concerns the conceptualization of the actors involved. As Fichter et al. (2011) recognize, the transfer of practices' model tends to simplify actors when assuming homogeneous interests within both the corporate and union groups. In some of the cases they study, the stable coalition on labour's side between GUFs, national unions at headquarters, and employee representative bodies was lacking, what explained the informal nature of the monitoring procedures. This question of actors' complexity is central in the continuous bargaining model. Egels-Zanden (2009) shows, for example, how change in top management can provide a CSR manager with support for the signing of a GFA. Other studies call for considering intra-group fragmentations revealed by IFA implementations, whether it is in the union (Dehnen, 2013) or in the managerial (Wickers and De Bakker, 2015) sides. The micropolitics approach, we argue in this article, addresses this problem of actors' complexity and offers, for this reason, a better understanding of GFAs. In acknowledging the fundamental heterogeneity of the managerial line and the union network, both vertically (between headquarters and subsidiaries or between GUFs and local unions) and horizontally (between the different managerial functions or between competitive trade unions), this approach allows for interpreting GFAs as a regulation of complex power relations in the TNC. It helps understanding complex unionsmanagement relationships like those identified by Niforou (2012) or Fichter and McCullum (2015). According to them, while the GFAs' negotiations are frequently collaborative with a rapid consent of both sides at the central level of TNCs, tensions emerge at local level when the GFA must be translated into concrete actions.

In this article, we propose to empirically explore the idea that GFAs reflect an alliance between a part of central management, the CSR managers at the headquarters, and a part of the union actor group, as embodied by GUFs. For each, the GFA is a means to achieve their objectives. To explore this conjecture, we conducted 97 interviews with managers and union leaders at the central level of 10 French TNCs who had signed GFAs. Our results confirm that GFAs are designed as a means to put union networks in a position where they can play an operational role in the monitoring of subsidiaries by applying local regulations and creating systems for the transfer of information from local unions to central management. Beyond this 
general trend, our results show variation in the monitoring devices adopted to activate these mechanisms. These findings support the micropolitics perspective on GFA and CSR and help understand the rationales for their adoption, the procedural dimension of their evolution and the diversity of their content.

The paper is organized as follows. The first section reviews the literature. The second section presents the methodology and sample of firms. The findings are summarized in section 3. In the last section, we discuss the practical implications and suggest new lines of enquiry for future research.

\section{Literature review}

a) GFAs: a diverse reality at the intersection of CSR and industrial relations

At the most basic level, a GFA is an agreement signed between a transnational company and one or more global union federations, whereby the TNC commits to respecting a number of social and societal engagements throughout its global operations. However, beyond this fundamental element, these agreements reflect extremely diverse realities in their formal content and practical implementation. The diversity of the formal content of these agreements is observable in four major dimensions:

1. The actors involved: In addition to the usual signatories (the management representative and person or persons who represent the union federations), other actors may be involved, such as those in national unions in the home country of the company headquarters and personnel representatives (in particular, European Works Councils);

2. The nature of the commitments: The first agreements signed were limited to guaranteeing the most fundamental human rights, typically referencing the basic norms of the International Labour Organization (ILO), but many agreements now include themes such as the promotion of diversity or the management of restructuring programs;

3. Methods of deployment (we develop this in more detail below): GFAs differ greatly in the manner that agreements are applied and deployed. Thus, different provisions may be included that concern the monitoring practices in the field (reporting tools, site visits, audit missions, etc.), the steering of the agreement (follow-up committee, the role of the unions in the system, etc.), or the procedures for managing conflict; 
4. The scope of application: By definition, GFAs have a worldwide field of application, which distinguishes them from the European framework agreements (EFA) that arose from a very distinct rationale, although GFAs and EFAs are often grouped together under the generic term transnational collective agreements (TCA) (Mustchin and Martinez Lucio 2017). Nevertheless, adjustments, although rare, can sometimes be seen (membership clauses for subsidiaries, exemptions for subsidiaries located in the United States, etc.). There is potential variation among GFAs regarding the scope of application and specific treatment applied to some categories of subsidiaries (those not fully controlled by the TNC, for instance) and to suppliers in the global value chain.

A wide variety of situations concern the content of signed agreements, but this diversity must be considered within a time perspective. The first GFA was signed in 1989 by the Danone group (BSN), and some time passed before this pioneering lead was emulated. It was only at the beginning of the 2000s that the practice truly began to develop, mainly in TNCs whose headquarters were located in mainland Europe. Notably, the number of agreements signed increased over the last two decades and there has been a clear development in the content of these agreements. There has been a strong tendency towards greater sophistication in the agreements, in both their content and the instruments for their implementation. This general trend is sometimes reflected at the individual firm level because existing agreements are frequently renegotiated within a company and the result is new agreements that are more ambitious and more demanding. Beyond descriptive analysis of the content of agreements and their development, academic research has largely been structured around the simple but fundamental question of the agreements' effectiveness: how do GFAs contribute to improving the situation and working conditions worldwide? There is no consensual answer to this question and estimations of the actual effects of GFAs in the field range from highly enthusiastic to highly skeptical.

These contrasting positions are likely a reflection of the wide variation in the agreements' content. There is diversity in concrete deployment, formal content, and in how the terms of the agreement are internalized by the actors concerned. The informal side of actors' practices and the actual application of these schemes are important. Additionally, instead of answering the question of the effectiveness of these agreements with a binary response, many authors whose work we discuss below identified conditions that determine the degree of the agreements' effectiveness. 
Other researchers focused on analyzing the impacts of GFAs, not in absolute terms but in comparison with those of codes of conduct. An example is the study carried out by EgelsZandén and Hyllman (2007). The authors view GFAs and codes of conduct as two different approaches to operationalizing TNC responsibilities for workers' rights in developing countries. According to Egels-Zandén and Hyllman (2007), these two approaches share the same aim but, whereas codes of conduct relate to a unilateral managerial strategy, GFAs are related to a contractual process and generally include unions in setting up an agreement. The authors' main proposal is that the impacts of these two approaches are differentiated according to whether we consider the direct impacts on workers' conditions or the impacts in terms of the enforcement of union rights. Referring to the idea of "workplace democracy" and distinguishing between its "outcome" and "process" components, Egels-Zandén and Hyllman observe that, by considering their capacity to obtain genuine respect for union rights, GFAs can be considered superior approaches to CSR than unilateral approaches in the form of codes of good conduct.

Although they do not refer explicitly to GFAs or codes of conduct, Donaghey and Reinecke (2018) propose an interesting comparative view of the two approaches. The authors, who are specialized in industrial relations, view CSR and industrial democracy as two paradigmatic approaches to transnational labor governance. As opposed to the initiatives that comprise a CSR approach and are characterized as unilateral, instrumental and managerial, initiatives using the 'industrial democracy' approach have the major advantage, according to the authors, of actively involving workers in the process, as the stakeholder group that is typically the most concerned beneficiaries. Taking a perspective similar to that of Egels-Zandén and Hyllman (2007) - notably using the metaphors of the "quick fix" and "long haul" - their study reveals that, although the CSR approach allows for short-term resolution of certain problems, the industrial democracy approach is necessary to build governance capacities involving workers in the long term.

However, the conceptual distinction established by Donaghey and Reinecke (2018) must not obscure the ambiguous nature of GFAs at the intersection between CSR and industrial relations. Notably, GFAs have been studied by researchers from both disciplines, which has led to publications in two types of academic journals. However, there has been little dialogue between researchers in these two fields. This is what led Egels-Zandén (2009), in particular, to propose a true research program that would combine the fields of industrial relations and business ethics. 


\section{b) GFAs and the micropolitics perspective on $H Q-S$ relations}

In CSR and industrial relations, many researchers note the central role of union actors in determining the degree of effectiveness of announced commitments (Fichter et al. 2011). Different lines of argument have been proposed to account for this role. Some authors stress the reinforcement of the power balance that is granted to unions through the GFAs and others highlight the fact that the involvement of the unions facilitates access to information about what occurs in the field. More generally, it is a central theoretical basis of our paper that the determining roles of union actors in GFAs may be determined by building on the micropolitics perspective of headquarters-subsidiaries (HQ-S) relations within TNCs. The micropolitics perspective views the TNC as a complex "political arena" (Helfen and Fichter, 2013). This approach is centered on the strategies of the various actors involved and on the capabilities that they developed at different organizational levels. The focus is on issues of power within a TNC, especially considering that the managers of subsidiaries have their own interests and may pursue goals that diverge from those of the headquarters (Dörrenbächer and Geppert 2006, 2011; Bouquet and Birkinshaw 2008). In this context, the will and impetus from headquarters are not sufficient to guarantee that managers in subsidiaries spontaneously apply the commitments of GFAs.

Furthermore, it can be argued that this main focus on HQ-S relations and monitoring practices in the field is most relevant when analyzing the implementation of CSR policy in TNCs. First, local managers may be prone to note the specificities of their local context to justify or request some adaptation of the general framework. Second, CSR departments, compared to others such as financial departments, may lack power and resources to promote their policy. By considering the diversity of the actors within a TNC and the different interests that characterize them, the micropolitics perspective accepts the possibility of specific alliances at different levels in the managerial line between managers and union actors. For example, Lévesque et al. (2015), building on the study by Kristensen and Zeitlin (2005), examine the way in which local actors seek to increase their margins for maneuver in relation to headquarters. They note that this quest for more discretionary latitude could lead the managers of subsidiaries and local union actors to form alliances when confronted with central managers. As developed below, we can envisage another kind of alliance that 
conversely unites local unions and central managers, specifically CSR managers ${ }^{1}$, against local management. As noted above, CSR departments may lack power and resources compared to other HQ central departments in TNCs. Thus, they can find themselves in a position of "low power actors" (Bouquet and Birkinshaw, 2008) at the HQ level, which leads them in a search for alternative sources of power in the hierarchy. Cooperation with local union representatives, in connection with the legitimacy resources provided by the GFA, is one way to exert influence and support CSR policy implementation in the field. This possible cooperation implies that union organizations could support the central CSR department in monitoring subsidiaries. The idea that local unions could support central management appears highly counterintuitive when one considers that the very existence of unions is based on the existence of a divergence of interests and a fundamental antagonism between capital and labor. If, in the case of GFAs, there is an apparently paradoxical cooperation between union organizations and central management, this is the result of the very specific scope of this circumstantial cooperation, i.e., the CSR policy, and the object of the monitoring process at issue. Thus, the possibility of mobilizing union actors in the process of monitoring subsidiaries has its origin in the existence of a zone of converging interests that relates to the respect for certain business policies concerning CSR and workers' rights, even if the motivation underpinning both sides is not the same. The main point is that this convergence of interests expresses and manifests itself as opposition to a possible divergence of interests on these same topics with the subsidiary managers.

From a functional point of view, envisaging union organizations as participants in the monitoring of subsidiaries is tantamount to recognizing the idea of a union network because this monitoring is based on local regulations and the capacity to transmit reliable and pertinent information to central managers. The unions are in a privileged position to collect information and know what is occurring in the field. Furthermore, it is generally considered in their own interests (and those of the workers they represent) to communicate information as soon as it is relevant regarding any dysfunction that is detrimental to the workers (Egels-Zanden and Merk, 2014). Monitoring devices associated with codes of conduct also make provisions for collecting this type of information via social audits. The audit methodology systematically includes exchanges with workers and union representatives, where there are any, but audit often encounters methodological difficulties (Egels-Zandén and Merck, 2014). In contrast,

\footnotetext{
${ }^{1}$ We use this title in a generic way to refer to the manager responsible for the negotiation and implementation of the GFA; in fact, she or he can be the industrial relations manager.
} 
GFAs have an interest in stimulating the union network by recognizing that global union federations play a coordinating role. By becoming a voice mechanism and acting as a mechanism for redress in cases of local difficulties that cannot be resolved, the intervention of GUFs allows for workers freedom of speech at a local level, paving the way for revelations about the non-respect of company policies by subsidiaries. In this sense, the recognition of the union network can play a central role in the monitoring of subsidiaries regarding CSR policy implementation.

Finally, in line with and complementary to the micropolitics perspective, other strands of literature have analyzed the role of union networks, most notably the works of Lévesque et al. (2016) and Helfen and Fichter (2013). Lévesque et al. (2016) place their analysis in the framework of the literature on multilevel governance. This concept accounts for the complex links between the levels of regulation within a TNC (local, national, regional and supranational) and, in this context, the manner in which the strategies of influential actors (headquarters, subsidiary managers, GUF, representatives of workers at national and local levels) are interconnected. In terms of monitoring in the TNCs, Lévesque et al. (2016) note that there are two clear approaches: one is centric, in which monitoring relies on a small number of actors at the central level, and the other is multilevel, where the monitoring is based on more complex mechanisms at different levels of the transnational firm. Helfen and Fichter (2013) approach the multiactor action associated with GFAs with a focus on the "transnational arena of labor relations". The core of their approach relies on the notion of "transnational union networks". In this perspective, the GUFs are analyzed as "network coordinators" that can activate their links with other actors and union networks with an aim of coordinating the workers within the transnational arena of industrial relations and conceiving appropriate responses. Helfen and Fichter (2013) highlight an important distinction, which corresponds to that established by Lévesque et al. (2016), between a multilevel approach and a centric approach. They distinguish between the transnational union networks that are located at the headquarters level and mainly built around relations between central actors of the TNC (home country trade unions, internal representation bodies of employees such as works councils, and global union federations) and the transnational union networks that are mainly based on connections established between the GUF at a central level and the affiliated union actors at local and national levels. 


\section{C) Implications for investigation of GFA dynamics}

To explore the idea of union networks as a pillar of the monitoring mechanism of CSR policy and understand the conditions for its effectiveness, it is necessary to scrutinize the concrete mechanisms associated with it and the internal relationships within management and unions. Following the micropolitics approach, we assume that the engagement of GUFs and CSR managers in GFAs can be understood via the position of each side.

To examine the different decision-making levels within TNCs and their implications for monitoring, Sydow et al. (2014) propose a multiorganizational practice perspective. They describe the diversity of decision-making actors involved in deployment and how the contents of negotiated GFAs are linked to implementation, conflict monitoring and resolution procedures. This approach to multiorganizational practice is founded on the observation that, beyond the formal duality of signatories, the design and deployment of GFAs often mobilize many levels of decision-making or influence. GFAs mobilize the central management of the group, one or more GUFs and, depending on the situation, local managers, national unions at the home country level, local unions at the level of the subsidiaries and even employee representatives (work councils) at the national level, or more frequently, the European level. In this context, Sydow et al. suggest that effective implementation of GFAs requires simultaneous implementation of three types of practices: information and communication practices; practices for training and dissemination of knowledge relative to the GFA; and practices qualified as operational, which are defined as the actions undertaken to change local conditions that lead to nonrespect of social norms. These practices can be initiated by management or unions or be the result of a joint approach. Among operational practices, monitoring and checking play a leading role and the authors distinguish between different monitoring practices according to the degree of union participation involved: 1) selfmonitoring by management; 2) monitoring by outside agencies; 3) the participation of union representatives in the monitoring process; and 4) monitoring directly by workers, i.e., workers who are union members.

As noted above, the participation of union representatives in the monitoring process may be interpreted as the manifestation of a cooperation between GUFs and CSR managers at the central level of TNCs. To fully understand this paradoxical cooperation, it is necessary to consider internal relationships within the management and the unions because GFAs are an opportunity for the negotiators to strengthen their positions. In each case, it is possible to 
differentiate the relationships occurring vertically between the central and local levels, and those occurring horizontally between same-level actors.

Table 1: Internal relationships in the managerial and the union sides

\begin{tabular}{c|c|c}
\hline & Vertical & Horizontal \\
\hline Management & HQ/Subsidiary & Inter-services coordination \\
\hline Trade-unions & GUF/Local union & $\begin{array}{c}\text { GUF/Company union(s) or } \\
\text { Union rivalry }\end{array}$ \\
\hline
\end{tabular}

Table 1 presents four main types of internal relationships that may influence why and how a GFA is implemented, illustrating the fact that the management and the unions should not be considered homogenous and unitary actors. To analyze the dynamics in the implementation of a GFA, particularly regarding the role of unions in the monitoring, we must consider the configuration of four relationships.

The first type of relationship, occurring vertically within the management, is the relationship between HQ managers (in our case, CSR managers) and subsidiary managers. When a TNC is highly integrated, the hierarchical power is sufficient for CSR managers to implement their policy. In the case of high differentiation, for institutional, cultural or historical reasons, the hierarchical power is not sufficient and CSR managers tend to develop alternative strategies. In a such a case, GFAs and the associated stimulation of union networks can be perceived by CSR managers as a source of power via the mobilization of the union network.

Second, CSR departments may be hindered in their actions by other functional services or strategic business unit managers at the HQ level. The latter can view CSR policy as an unnecessary constraint that is in conflict with their business objectives and priorities. It follows that, in case of weak interservices coordination when each service pursues its own objectives, CSR managers experience difficulties in implementing their policy.

A third type of relationship relates to the union side, which can be less integrated than supposed in the literature. The capacity of the GUF to coordinate the union network depends on its resources and legitimacy in the eyes of local unions. As they are meta-organizations 
(Karlberg and Jacobson 2015), GUFs can experience a weak position vis-à-vis local unions. For CSR managers, the GUFs' power in coordinating the union network is linked to the integration degree of the network. Notably, GUFs and local unions do not necessarily share the same interest in GFA implementation.

From a horizontal perspective, this leads to a focus on the relationships between the GUFs and the national unions in the TNC home country or among national unions in countries with union pluralism, such as in France. This attention given to the union relationships at the central level may highlight the possibility of different union strategies regarding the GUF(s) and the GFA, which is potentially an important issue in the French context where several unions typically coexist and compete with one another in big companies.

According to the micropolitics conceptualization of GFAs, we consider a GFA to be particularly relevant when two conditions are filled: when central CSR managers are lowpower actors because of high differentiation and low interservices coordination and when the union network is integrated. TNCs are rarely so stereotyped, and characterizing these internal relations will help understand the issues associated with GFAs. Notably, the degree of union network integration is not known by CSR managers, who base their strategy on a perceived degree of integration.

\section{Methodology}

To analyze GFAs as a mechanism for monitoring subsidiaries by central CSR managers, we conducted 97 face-to-face interviews ${ }^{2}$ with actors in different industrial sectors implied in the GFAs signed by 10 French TNCs (see the sample description in table 2).

Table 2: Signatories and themes of the GFAs

\begin{tabular}{l|l|l|l}
\hline & $\begin{array}{l}\text { Intemational } \\
\text { union }\end{array}$ & Publication* & Scope \\
\hline Carrefour & UNI & $\begin{array}{l}2015 \\
\text { (prev. 2001) }\end{array}$ & $\begin{array}{l}\text { Social dialogue, diversity; to ensure } \\
\text { the protection of fundamental } \\
\text { principles and rights in the workplace }\end{array}$ \\
\hline Danone & UITA & 2016 & $\begin{array}{l}\text { Sustainable employment and access to } \\
\text { rights }\end{array}$ \\
\cline { 3 - 4 } & 2011 & $\begin{array}{l}\text { Health, safety, working conditions, } \\
\text { stress }\end{array}$ \\
\cline { 3 - 4 } & 2007 & Diversity \\
\hline
\end{tabular}

\footnotetext{
${ }^{2}$ Interviews with international union representatives were conducted via telephone.
} 


\begin{tabular}{|c|c|c|c|}
\hline & & $\begin{array}{l}2005 \\
\text { (prev. 1992) }\end{array}$ & Skills training \\
\hline & & $\begin{array}{l}2005 \\
\text { (prev. 1994) }\end{array}$ & Trade union rights \\
\hline & & 2005 & $\begin{array}{l}\text { Setting up social indicators at group } \\
\text { level }\end{array}$ \\
\hline & & 2005 & Fundamental social principles \\
\hline & & $\begin{array}{l}2005 \\
\text { (prev. 1989) }\end{array}$ & $\begin{array}{l}\text { Promotion of gender equality in } \\
\text { workplace }\end{array}$ \\
\hline & & $\begin{array}{l}2005 \\
\text { (prev. 1989) }\end{array}$ & Economic and social data \\
\hline & & $\begin{array}{l}2005 \\
\text { (prev. 1997) }\end{array}$ & $\begin{array}{l}\text { Changes in business activities } \\
\text { affecting employment or working } \\
\text { conditions }\end{array}$ \\
\hline & & 2001 & $\begin{array}{l}\text { Social standards applicable in } \\
\text { restructuring of biscuits division in } \\
\text { Europe }\end{array}$ \\
\hline & & 1998 & $\begin{array}{l}\text { Common viewpoint on fundamental } \\
\text { social principles }\end{array}$ \\
\hline$\overline{\mathrm{EDF}}$ & PSI & $\begin{array}{l}2009 \\
\text { (prev. 2005) }\end{array}$ & Social responsibility \\
\hline Engie & $\begin{array}{l}\text { BWI, } \\
\text { IndustriALL, } \\
\text { PSI }\end{array}$ & 2014 & Health and safety \\
\hline & PSI & 2010 & $\begin{array}{l}\text { Fundamental rights, social dialogue, } \\
\text { sustainable development }\end{array}$ \\
\hline Orange & UNI & 2006 & Health and safety \\
\hline PSA & IndustriALL & $\begin{array}{l}2017 \\
\text { (prev. 2010, } \\
2006)\end{array}$ & Social responsibility \\
\hline Renault & IndustriALL & 2013 & $\begin{array}{l}\text { Social, societal and environmental } \\
\text { responsibility }\end{array}$ \\
\hline $\begin{array}{l}\text { Société } \\
\text { Générale }\end{array}$ & UNI & 2015 & Fundamental rights \\
\hline Solvay & IndustriALL & $\begin{array}{l}2017 \\
\text { (prev. 2015) }\end{array}$ & $\begin{array}{l}\text { Social responsibility, sustainable } \\
\text { development }\end{array}$ \\
\hline Total & IndustriALL & 2015 & CSR \\
\hline
\end{tabular}

Note: * "prev." indicates the date of the previously signed GFAs on the same topic.

The semistructured interviews were conducted from January to June 2017 by a multidisciplinary team of researchers and lasted approximately one hour, on average. The interviewees were directly or indirectly concerned with setting up GFAs. In each case, the negotiators on the management and GUF side were questioned, and the sample was widened to other actors involved in the implementation of the GFA (human resources management, company unions) or constrained by it (purchasing, compliance, finance). These actors were at 
the central level of the transnational companies because our aim was to understand the manner in which these actors conceive of, implement and equip GFAs. The interviews were audio recorded and transcribed. Table 3 provides details of the interviews by the TNC and type of function. We also conducted a parallel qualitative analysis of GFA documents to study their content and scope. The comparison of their content is of particular interest to understand GFA monitoring mechanisms. Table 2 shows the main characteristics of the GFAs, including the signatories, dates and themes.

Table 3: Interviews

\begin{tabular}{|c|c|c|c|c|c|}
\hline & \multicolumn{2}{|c|}{ Representing management } & \multicolumn{2}{|c|}{ Representing staff } & \\
\hline & $\begin{array}{l}\text { Function } \\
\text { HR/IR/CSR }\end{array}$ & $\begin{array}{l}\text { Other } \\
\text { functions }\end{array}$ & $\begin{array}{l}\text { Global Union } \\
\text { Federations }\end{array}$ & $\begin{array}{l}\text { Representatives of } \\
\text { company workers or } \\
\text { national union } \\
\text { federations }\end{array}$ & \\
\hline Carrefour & 2 & 3 & 1 & 2 & 8 \\
\hline Danone & 7 & 0 & 1 & 1 & 9 \\
\hline EDF & 2 & 6 & 1 & 3 & 12 \\
\hline Engie & 3 & 0 & 4 & 2 & 9 \\
\hline Orange & 4 & 2 & 1 & 2 & 9 \\
\hline PSA & 2 & 2 & 2 & 2 & 8 \\
\hline Renault & 3 & 4 & 2 & 3 & 12 \\
\hline $\begin{array}{l}\text { Société } \\
\text { Générale }\end{array}$ & 5 & 2 & 0 & 1 & 8 \\
\hline Solvay & 1 & 2 & 1 & 4 & 8 \\
\hline \multirow[t]{2}{*}{ Total } & 5 & 5 & 2 & 2 & 14 \\
\hline & 34 & 26 & 15 & 22 & 97 \\
\hline
\end{tabular}

The interview guide was adapted to each interviewee but contained different sections that were derived from the literature review and conceptualization work. The first part of the interview addressed the initiative surrounding the GFA and its history. The second section 
addressed the negotiation of the GFA and the relations between the different partners in the agreement, its content, scope of application and articulation with other company policies. The third part concerned the monitoring of the GFA and reporting systems, and the final part discussed the use of the agreement by CSR managers to implement local social dialogue at the local level.

Our methodology and sampling have many advantages. Semistructured interviews have some methodological and practical advantages. Semistructured interviews allow for the opportunity to talk in private with individuals at length and without interruption. Such an approach was useful in the earlier stages of our study in which we were developing relationships with organizations and individuals and learning about them. Moreover, studying different TNCs from the same country has at least two advantages: we cover different industrial sectors and account for sectoral differentiations, and we can control for any country-of-origin effects although subsidiaries are located in different parts of the world, allowing for variations in contexts. Our focus on France resulted from the relative advancement of this country in terms of GFA adoption by TNCs.

To ensure internal validity and reliability, a constant comparative method was utilized (Barnes 1996). We compared the output from the data to existing theory to enhance internal validity (Eisenhardt 1989). Triangulation with secondary sources and interviews of different actors inside and outside the TNCs - allowed for understanding different perspectives on the same phenomena and increased external validity.

The transcripts were read by all the authors, who identified the most significant verbatim quotes. We looked for patterns based on frequency, commonalities, and differences (Saldaña, 2013). We discussed and developed a coding frame. Each author took notes on subthemes, noting the relevant descriptions and facts in the interviews and reported corresponding quotes. Comparisons and discussions on disagreements allowed for us to reach consensus and triangulate the coding of the interviews. This coding allowed for us to develop analytical categories that revolved around the reporting tools (before and after the GFA, the role of unions in the reporting tools, the typical process to signal a problem occurring in a subsidiary, etc.), the roles of joint committees (composition, role, used to promote good practices, used to manage problems, useful to validate the managerial policy), the union network (connections with local unions, stability of the team) and the nature of the horizontal and vertical relationships between actors. This categorization was useful to analyze the emerging 
dimensions that are developed in the results: GFAs as the continuation of a managerial policy and the diverse logic underlying the follow up of GFAs. The interview transcripts were reviewed in detail to detect patterns and regularities.

In the second analytical stage, we applied theory building, which enabled us to induce categories of monitoring mechanisms via GFAs. Using constant comparison and interpretation, we inductively derived four categories of monitoring, presented in the findings, reflecting the data: managerial, jointly led, structuring or exploitation. This systematic analysis, using triangulation for the categorization in the first stage, increases the confidence in our findings.

\section{Findings}

Following the micropolitics perspective, GFAs are seen as a means for the CSR managers in headquarters to stimulate the union network, which they perceive as allies in overcoming skepticism from management in peripheral services or subsidiaries. The cases confirm that GFAs rarely incorporate new rights, as in a collective bargaining approach, and are mainly in line with existing managerial policies. We identify a diversity in the operational role of trade unions in the implementation of GFAs, ranging from a unilateral conception of implementation to a coordinated one.

\section{a) GFAs in line with managerial policies}

The literature devoted to GFAs is cautious in distinguishing them from managerial policies in matters of CSR. This is because the latter are so-called unilateral approaches, in the sense that it is up to management to define the content of CSR initiatives and how they are implemented. The GFAs, in contrast, are joint approaches of the employer and workers' representatives. The content and means of implementation are decided jointly, and this can change their nature substantially. However, this is less marked than one might hypothesize. A company's unilateral policies and the joint approaches coexist and constrain each other dialectically. In most of the cases studied, the GFA appears to be in line with pre-existing managerial policies. This may indicate a geographic extension, a marginal improvement in the content of commitments or setting of company policy in a contractual form. The health and safety agreement signed by Engie in 2014 can thus be seen as a typical prolongation of a policy that was already inscribed in the 2010 European agreement, which was considered a group policy applicable to all subsidiaries. In the case of Total, the management explained that, "In this 
agreement, we have consolidated, we have given meaning and wider publicity, but we have also looked again at some dimensions or some arrangements that were present in many countries around the world but not all. Finally, this has helped to bring more coherence and to deploy more widely measures that were already largely in place." The health and safety agreement signed by Orange demonstrates a similar philosophy because it was presented as a territorial extension to the group's health and safety at work management system, which, in the eyes of management, needed to be more uniform to make efficiency gains. This statement confirms that the expectations of central actors, especially at headquarters, are not as concerned with the substantial content of GFAs as with the procedural aspects, as a tool for the transfer of practices within the TNC. For the director of industrial relations at the Société Générale, a GFA is "close to a charter but more effective than a charter". For Orange, the GFA allows for the uniformization of practices within the group. For EDF, "it brings real scope to negotiating and being able to contractualize with social partners; it brings more weight than a managerial-level decision that would be applied only because it had been defined". This proposition of the greater effectiveness of agreements compared to unilateral approaches appeared regularly in the statements of representatives from human resources or industrial relations and, more explicitly, by the industrial relations director at Solvay: "A code of conduct is something carried out by general management for the attention of the rest of management. The point of this code is whether the code of conduct is respected. Who can you rely on to be sure it is followed? You can rely on management. In addition, if management behaves badly, they are not going to say, 'I'm behaving badly, and I'm not respecting the code of conduct', so it's true that the system of staff representation is actually a parallel system that allows for the inevitable imperfections to be ironed out, whatever the qualities of the managers, or of the current managerial system."

Throughout this theme of effectiveness and efficacy, several interconnected arguments emerge that call for a better link between the identified aims of the agreement and the monitoring mechanisms. In some cases, the expected benefit was expressed in terms of increased legitimacy. In a rather counterintuitive manner, those responsible in central services count on the commitment made by the company and its highest authorities regarding social partners to justify their approach, which might appear to be bureaucratic constraints that the subsidiaries tend to ignore. For these leaders, the main interest of the GFA is to legitimize managerial policy. Others highlight the benefits of dialogue. Through discussion with workers' representatives, who have good knowledge of the company, it is possible to improve 
managerial policy. A third benefit lies in the ability of workers' representatives to take operational charge of the monitoring of subsidiaries to oblige local management to apply group policy. This third benefit corresponds to our hypothesis, that central managers aim to create a monitoring mechanism to force subsidiaries to apply the company's policies via GFAs.

\section{b) Centralized monitoring and mobilization of the union network}

In a near-systematic manner, GFAs' monitoring devices and the policies they are supposed to disseminate throughout the group are based on a plurality of mechanisms. This plurality makes the "mechanics" of a GFA difficult to interpret for the actors and can crucially limit its effectiveness. If we focus on the actors involved in monitoring, our observations corroborate the idea that the union network presents itself as an alternative monitoring device that complements the more classic centralized arrangements.

\section{Centralized monitoring by management}

At a central level, monitoring can be almost the exclusive responsibility of management. This is the case when a reporting system or audit is set up by management, who devises and carries it out. Information collected in this manner helps management to conduct and adjust its policies as it feeds the agreement's central monitoring body. At EDF, discussions within the follow-up committee must be based on a summary document created by the industrial relations department, with the risk that this document will only be partially assimilated by the workers' representatives, as a union representative and member of the follow-up body recounts: "Now, it's very exhaustive, it's absorbing, but it's an enormous thing that is not at all lively and that seems to have no direction; there are no aims, there are no indicators, so when you've read it twice, you find it interesting, yet it doesn't seem to serve any purpose." At PSA, the reporting mechanism is a joint effort, and the 60 monitoring indicators were determined by the group work council, but, operationally, the supply of information is ensured by the managerial line via a self-evaluation device managed by the director of industrial relations. In these monitoring devices, which are simultaneously centralized and under the responsibility of management, it is clear that the union organizations play only a minor role, limited to ongoing discussions. 


\section{Exploitation of the union network}

Another monitoring logic systematically appears among the CSR and industrial relations managers and echoes our proposition. This logic consists of enacting local mediation and sending information back to management via the union. It can be viewed as the classic union voice effect: "What interests us too is that this global union federation, which is linked up in every country by affiliates, could also be a vector for alerts, a vector for attention, or a warning sign sometimes and that suits us" (Carrefour).

This voice effect is a condition for CSR managers to do their job. Without information on the actual problems and issues at the local level, they cannot manage them and control for social risks. These managers may think that the problems will not emerge spontaneously. In other words, the managerial line is not perceived as the relevant channel to identify social or ethical problems. For example: "What interests me is that the problems are laid on the table. Because, while they are not out, you can't handle them. They have to be made to emerge. In addition, basically, difficult problems are not going to emerge spontaneously” (Solvay).

The underlying concept is that the union network is better organized than the managerial network and therefore constitutes an opportunity for central management. This idea is found in interviews at EDF and Engie: "The unions are much better organized than us, so it trickles through more quickly, and what's more, there are the global federations, which add their input, and they are certainly capable of making a kind of strike force to put their finger on what's causing the problem" (EDF). At Engie, unions' communication is praised: "Union organizations have much better communication than us: they've known how to use worldwide networks much longer than us. I've always been amazed, over the years, to see the information that comes out by mail or Internet, or whatever; they all know that something's up in, I don't know, Colombia, and us, we've known nothing about it. Hierarchical networks don't work, but the union networks work really well. That's always been the case, and I think it's a good way of working" (Engie).

The more tightly organized the union network is perceived, the more opportunistic it is for central IR managers to deal with its representatives: "It's a permanent network, it's a permanent, tightly knit network. There are only 11 individuals on the restricted committee. However, these 11 take care of everybody else as well. As its name suggests, it's the committee; they are elected by the 40 members, and each member is in contact with part of the world. They write to each other and they phone each other every month." (Renault). 
The following statements elucidate one of the core arguments for signing a GFA. The function of the union network is to challenge local management and to pressure it to apply corporate policies. This idea is found in the interviews with Orange and Total for example: "Therefore, in the unions as well, we are aware that they are being given responsibility so that they can go and challenge the management: "Hey there, your corporate actually told us that we should take an interest in this" (Orange); "The idea behind all this, that underpins this type of agreement, is that as a group we are going through change, such as many other firms and that we need to mobilize the personnel, that we need other channels besides the usual ones for the managerial line in particular, to send information back up the line in order to mobilize the personnel and we need to have another way of looking, to be challenged and to have a countervailing power that keeps an eye on what we are doing" (Total).

Several benefits are expected: the pressure exercised by the unions to "challenge" local management, which may not be diligent in regard to implementation, and the use of the union channel to send back information, which is deemed more efficient than the managerial channel. This kind of argument was present in each of the firms investigated, but closer observation revealed that the operational translation of this logic varies greatly. Some companies have a very strict interpretation of the principle of neutrality vis-à-vis workers' representatives in the subsidiaries and count on the federations to ensure development of the union network. This means the global federations undertake the task of developing the network within the company. This is the case at Sociéte Générale, where the agreement signed in 2015 provided for "Société Générale managers in every country [to] create a free and open environment in matters of union rights and freedom." The agreement stipulates: "To allow staff to really exercise their right to union freedom, the local affiliate of the UNI Global Union and local Société Générale managers will agree on the means of access within the company that are adapted to the specific operational context to allow the local affiliate to explain the advantages of belonging to a union and supporting it." In other words, the development of the union network is not hindered, but neither is it the object of active intervention by management, as confirmed in the interviews with representatives from international HR. This neutrality often goes hand-in-hand with a nurtured independence between the union channel and the managerial channel. The monitoring of the agreement by Engie is evidence of this: the overview takes the form of an "exchange about the results and the indicators presented by management: We always begin with a sequence of results to know where we stand, we talk about the most serious accidents, obviously in terms of sharing 
information [...] And then, conversely, the representatives of different federations also make their comments or pass information up" (Engie). In these cases, we can therefore see that there is a logic to exploitation of the union network, as the company considers that, by recognizing the global federations, the GFA will help utilize and reinforce the pre-existing union network.

\section{c) Coordination of the managerial and union channels}

Centralized monitoring by management and exploitation of the union network appear to be two independent monitoring mechanisms that maintain a certain unilaterality. Their coexistence is often perceived as complementary. However, we observed another approach in some of the companies that consisted of attempts to coordinate the mechanisms by enacting joint centralized monitoring or attempting to structure the union network.

\section{Joint centralized monitoring}

Centralized monitoring can give union organizations a more important position. This is the case at Danone and Solvay, which initiated the practice of regular joint site visits to check that the agreement is being applied correctly. The team conducting these visits - known as the "panel" at Solvay - is made up of management and union representatives, who talk directly to local managers about the corrections that must be made. Here, the union organizations play an operational role and are sometimes responsible for producing the minutes of the meetings. The approach remains centralized in the sense that it is a team composed of central actors who conduct the monitoring, with an aim of verification. To a lesser extent, Renault reinforces the joint dimensions of centralized monitoring by sending members of the follow-up committee into the field. In these cases, it is less of a monitoring visit and more of a learning session that allows for the central personnel representatives to obtain a better idea of the realities of the terrain and to play more active roles in creating managerial policies.

\section{Structuring the union network}

Other firms chose a voluntary policy to activate the union network and guarantee the efficacy of local social dialogue. The GFA signed by Orange stipulates that the group gives its subsidiaries the responsibility for creating committees to pilot health and safety policies locally. This GFA is original in that it emphasizes the procedure rather than the content of the group's health and safety policy, merely summarizing the main principles. With respect to the main principles, the purpose is to design locally adapted policies. For the management 
representatives, the policy must be constructed in the field; this presumes a flexible agreement that is built over time. The keystone of the device is the local committee, whose existence and efficiency must be guaranteed. To do so, the firm's internal union network on the scope of the group, known as the "Alliance", and members of management act jointly to identify the local actors who can best pursue this initiative. For each committee, a combined two-person steering team with one employee representative and one management representative is identified. Resources for local dialogue also take the shape of a local diagnosis commissioned by the headquarters and made available to the local committee. Orange stands out here because the logic is less concerned with exploiting a union network whose development and animation are entrusted to the GFA than it is with structuring the union network through a voluntary managerial policy. One notable lever for building a union network is central management's voluntary recognition of the network by instituting a coordinator, internal to the company, who takes charge of the animation that, in principle, is entrusted to the union federations that signed the agreement. This practice is strongly defended by UNI Global Union, which seeks the recognition of the "Alliance". In our sample, we found instances of the "Alliance" in Orange, Société Générale and Carrefour, all three of which are signatories of the UNI Global Union. Other companies have voluntarily recognized an internal union facilitator on a worldwide scale. This is the case for Solvay's Global Forum. At Renault and PSA, the group work council has taken this role. The coexistence between these internal coordinators and the global federations can be a source of tension but it makes the union network more efficient.

These efforts to structure a union network by imposing local structures for social dialogue or by recognizing an internal union coordinator on a worldwide scale are a clear response to the difficulties encountered in exploiting union networks. The 2015 renegotiation of Carrefour's GFA is understandable from this point of view. Following the Rana Plaza disaster ${ }^{3}$, where the company was suspected to be at fault, the head of CSR stated: "We need people in the factories who are able to check that there is good maintenance. This is clearly something we can do through the union representatives or through the health and safety committees, but on this point, we are in fact accompanied by the unions in order to set up training programs in the factories and to create effective health and safety committees." This view is shared by the global federation, which notes that the existence of an active network implies that there is a

\footnotetext{
3 The Rana Plaza collapse was a structural failure that occurred on April 24, 2013, in Bangladesh. A total of 1,134 people died and 2,500 were injured. It is considered the deadliest garment factory accident and the deadliest accidental structural failure in modern human history.
} 
proactive movement towards unionization. Similarly, at Solvay, a central manager explained: "At IndustriALL, there are not enough of them. In the company, we manage to find the forces, but on the union side, it's more complicated. We have to help them by recognizing them as fully legitimate interlocutors. However, above all, they need to reinforce their structure and their functioning and to have local representatives trained in this kind of dialogue."

d) Diversity in monitoring mechanisms

Finally, our observations allow for the identification of four types of monitoring logic regarding mobilization of the union network (Figure 1), which can be organized on two dimensions. On the one hand, they reflect the consideration of a multilevel analysis of the split between centralized monitoring and monitoring that is reliant on the union network and, on the other, they reflect the degree of coordination between the union and managerial process - i.e., the space given to unions in centralized monitoring and/or how the union network is ultimately reinforced and structured through the agreement. The first dimension largely echoes the two types of approaches in matters of monitoring social policies in TNC proposed forward by Lévesque et al. (2016). Centralized monitoring corresponds to the centric approach, which consists of organizing monitoring of local levels (subsidiaries) under the direction of the central level (headquarters). The classic tools for this are reporting and audits. Monitoring based on the union network refers to a multilevel approach that consists of organizing monitoring at different levels of the firm with networks of watchdogs and/or local monitoring devices. The desire to mobilize the union network is part of this second approach. Considered in their purest forms, these two approaches are based on different logic that often coexists where GFAs are concerned (Fichter et al. 2011). Central management takes centralized monitoring in hand, whereas the union network drives local regulations. The second dimension opposes a unilateral conception of managerial and union process with a coordinated conception. Centralized monitoring could be carried out jointly. These four types of monitoring mechanisms comprise a continuum that is useful for systematic analysis of the role of union organizations in monitoring. At the extremes of this continuum, we found unilateral mechanisms: centralized monitoring by management and the exploitation of the union network. We also found intermediary mechanisms based on coordination of managerial and union processes, with the logic of reinforcement of the centralized monitoring by union organizations or management's structuring of the union network. 
Figure 1. The logics underlying the monitoring of GFAs

\begin{tabular}{||c|c|c|c|}
\hline \multicolumn{2}{|c|}{ Centralized monitoring } & \multicolumn{2}{c|}{ Union network } \\
\hline Managerial & Jointly led & Structuring & Exploitation \\
\hline \multirow{4}{*}{ Coordinated } & Unilateral \\
\hline
\end{tabular}

In Table 4, the principal monitoring mechanisms of GFAs in each of the companies studied is organized into four categories. A system of internal reporting and a system for filtering problems are often enacted simultaneously. Similarly, the existence of coordinated action between the managerial and union channels does not exclude a device for reporting that is steered by management. In the case of Orange, the logic of a dual follow-up, local and central, is clearly present, with a system of managerial reporting and close steering of the local social dialogue. At Orange, as in most other companies, it appears that unilateral approaches reach their limits very rapidly. Concerning the reporting system, we learn that "It's very complicated to get news back and up because, behind the labels, people don't put the same thing. Therefore, getting any coherent figures is not at all straightforward, and we are having a hard time. We need at least four or five months to have more or less complete information for the dashboard."

The case of EDF noted above shows that unilateral reporting conducted by central management may be appropriated by union representatives with some difficulty; this does not always inform dialogue in the follow-up committee. Similarly, the exploitation of union networks frequently runs against insufficient local union membership and a lack of means from global federations to ensure effective coordination and development. The data do not allow for comment on the efficiency of the mechanisms coordinating the union and managerial aspects, as this would require local observation, but they reinforce each other mutually. By structuring the union network, Orange ensured that the information provided to the follow-up committee was reliable. The joint visits organized by Danone and Solvay and, to a lesser extent, the learning sessions at Renault, relate to centralized monitoring because they concern sending central actors into the field but they also allow for reinforcement of the union structure. 
Table 4. Principle monitoring mechanisms in the companies studied

\begin{tabular}{|c|c|c|c|c|}
\hline & $\begin{array}{l}\text { Managerial- led central } \\
\text { monitoring }\end{array}$ & Jointly led central monitoring & Union network structuring & Union network exploitation \\
\hline Carrefour & & $\begin{array}{l}\text { Dedicated follow-up } \\
\text { committee }\end{array}$ & $\begin{array}{l}\text { Strengthening of the global } \\
\text { union network through the } \\
\text { voluntary participation of an } \\
\text { internal coordinator } \\
\text { ("Alliance") }\end{array}$ & $\begin{array}{l}\text { Problem filtering: priority } \\
\text { given to local conflict } \\
\text { resolution between local } \\
\text { management and local unions. } \\
\text { GUF can alert central } \\
\text { management in cases of } \\
\text { critical problems. It is the } \\
\text { GUF's responsibility to drive } \\
\text { the union network }\end{array}$ \\
\hline Danone & Internal reporting & $\begin{array}{l}\text { Joint visiting: representatives } \\
\text { of GUF and HQ visit } \\
\text { subsidiaries (the firm gives } \\
\text { financial support to GUF for } \\
\text { that); dedicated follow-up } \\
\text { committee }\end{array}$ & & \\
\hline $\mathrm{EDF}$ & Best practices collection & $\begin{array}{l}\text { Dedicated follow-up } \\
\text { committee }\end{array}$ & & $\begin{array}{l}\text { Problem filtering: priority } \\
\text { given to local conflict } \\
\text { resolution between local } \\
\text { management and local unions. } \\
\text { GUF can alert central } \\
\text { management in cases of } \\
\text { critical problems. It is the } \\
\text { GUF's responsibility to drive } \\
\text { the union network }\end{array}$ \\
\hline Engie & $\begin{array}{l}\text { Internal reporting; best } \\
\text { practices collection }\end{array}$ & $\begin{array}{l}\text { Dedicated follow-up } \\
\text { committee }\end{array}$ & & $\begin{array}{l}\text { GUF are supposed to deliver } \\
\text { their own information in the } \\
\text { dedicated follow-up } \\
\text { committee }\end{array}$ \\
\hline
\end{tabular}




\begin{tabular}{|c|c|c|c|c|}
\hline & & & $\begin{array}{l}\text { Strengthening of the global } \\
\text { union network through the } \\
\text { voluntary participation of an } \\
\text { internal coordinator } \\
\text { ("Alliance") }\end{array}$ & \\
\hline Orange & Internal reporting & $\begin{array}{l}\text { Dedicated follow-up meetings } \\
\text { by the global work council }\end{array}$ & $\begin{array}{l}\text { Central management compels } \\
\text { subsidiaries to establish a joint } \\
\text { health and safety committee; } \\
\text { procedural resources and } \\
\text { training are delivered by } \\
\text { central management to } \\
\text { implement such committees }\end{array}$ & \\
\hline PSA & $\begin{array}{l}\text { Internal reporting; best } \\
\text { practices collection; central } \\
\text { management compels } \\
\text { subsidiaries to establish a } \\
\text { local action plan and to } \\
\text { complete an auto-evaluation } \\
\text { survey designed by central } \\
\text { management every } 3 \text { years }\end{array}$ & $\begin{array}{l}\text { Dedicated follow-up } \\
\text { committee }\end{array}$ & $\begin{array}{l}\text { Active role played by global } \\
\text { works council }\end{array}$ & $\begin{array}{l}\text { Where a local union exists, it } \\
\text { is consulted on action plan } \\
\text { and auto-evaluation survey }\end{array}$ \\
\hline Renault & Internal reporting & $\begin{array}{l}\text { Dedicated follow-up meeting } \\
\text { by the global work council; } \\
\text { annual learning sessions for } \\
\text { work council members in a } \\
\text { country where Renault is } \\
\text { operating }\end{array}$ & $\begin{array}{l}\text { Active role played by global } \\
\text { works council }\end{array}$ & $\begin{array}{l}\text { Problem filtering: priority } \\
\text { given to local conflict } \\
\text { resolution between local } \\
\text { management and local unions. } \\
\text { GUF can alert central } \\
\text { management in cases of } \\
\text { critical problems. It is the } \\
\text { GUF's responsibility to drive } \\
\text { the union network }\end{array}$ \\
\hline
\end{tabular}




\begin{tabular}{|c|c|c|c|c|}
\hline $\begin{array}{l}\text { Société } \\
\text { Générale }\end{array}$ & Internal reporting & $\begin{array}{l}\text { Dedicated follow-up } \\
\text { committee }\end{array}$ & $\begin{array}{l}\text { Strengthening of the global } \\
\text { union network through the } \\
\text { voluntary participation of an } \\
\text { internal coordinator } \\
\text { ("Alliance") }\end{array}$ & $\begin{array}{l}\text { Problem filtering: priority } \\
\text { given to local conflict } \\
\text { resolution between local } \\
\text { management and local unions. } \\
\text { GUF can alert central } \\
\text { management in cases of } \\
\text { critical problems. It is the } \\
\text { GUF's responsibility to drive } \\
\text { the union network; the GUF is } \\
\text { defined as a mediator between } \\
\text { workplace unions and local } \\
\text { management }\end{array}$ \\
\hline Solvay & & $\begin{array}{l}\text { Auditing by a joint committee } \\
\text { ("panel") in charge of the } \\
\text { annual assessment report; } \\
\text { dedicated annual follow-up } \\
\text { meeting between central } \\
\text { management, unions and GUF }\end{array}$ & $\begin{array}{l}\text { Strengthening of the global } \\
\text { union network through the } \\
\text { voluntary participation of an } \\
\text { internal coordinator (Solvay } \\
\text { Global Forum) }\end{array}$ & \\
\hline
\end{tabular}




\section{Discussion and conclusion}

Our first objective in this research was to describe, conceptualize and explore a conjecture that regularly underpins practitioners' discourse and academic research dedicated to GFAs. In mobilizing the micropolitics perspective on HQ-S relationships, we considered GFAs as an alliance of CSR managers and central actors within unions to improve the effectiveness of social and labor policies throughout TNCs. This echoes the work of Egels-Zandén and Hyllman (2007), according to which GFAs are more effective than codes of conduct because of their processual dimension in terms of workplace democracy. By stimulating the union network and the emergence of local regulations, and by allowing CSR managers access to subsidiaries, GFAs enable local managers to be disciplined when monitoring is complex and costly for CSR managers. CSR managers no longer view the social dialogue as a constraint but as a lever in the transfer of practices within the TNC (Fichter et al. 2011), especially in the case of low-power actors, as is often the case in HR, industrial relations or CSR departments. In doing so, we reconciled two theoretical perspectives: GFAs as the result of continuous bargaining and GFAs as partnerships for transferring business ethics practices in TNCs.

As shown by the literature on international management, and especially the micropolitics perspectice, HQ-S relationships are political as well as functional. Local management frequently seeks greater flexibility over corporate policies to better fit with the economic, institutional or cultural constraints they face. The management at the headquarters attempts to standardize practices to better monitor subsidiaries. The classic debates in organization theories (Lawrence and Lorsch, 1967, for example) are particularly important when considering business ethics or CSR policies which must, more than other operational policies, be embedded locally. For the CSR managers, the aim is to gain power over the subsidiaries, in a vertical manner, and over peripheral services, in a horizontal manner. Business ethics policies have repercussions on services such as operations, purchasing, compliance or finance, which can resist if these repercussions conflict with their own policies.

Our results contribute to the literature on GFAs in three different ways. First, our empirical investigation of 10 French TNCs allows identifying a complementary rationale for signing a GFA. The cases highlight the fact that central CSR managers aim at increasing their monitoring capacity on the TNCs' subsidiaries. Deriving from this observation, we can hypothesize that CSR managers are more inclined to sign a GFA when they experience difficulties in monitoring their subsidiaries, due to a high level of differentiation or a lack of 
resources. In signing a GFA, they hope the GUF coordinator will stimulate the union network, which is perceived as an ally in the implementation of CSR policy. A TNC should move towards a GFA when its subsidiaries have strong autonomy from the headquarters and when its central services are loosely coordinated or when the union network is sufficiently integrated to provide credibility to the GUFs' intervention towards local unions.

Second, our results show how the concrete monitoring mechanisms adopted by each TNC can be analyzed in regard to this monitoring objective. In almost all cases, CSR or industrial relations managers report disappointment regarding the capacity of GUFs to coordinate the union network. An HR manager expresses this clearly when explaining: "We asked them, 'Where are you with your federations? Did you disseminate the agreement?' At this moment, silence. They also experience difficulties. But I understand because GUFs have to manage affiliated. And we must recognize this fact. It is not as in a company with hierarchy". In the cases of Solvay, Danone and Carrefour, this observed difficulty for the GUF in ensuring monitoring operationally resulted in the CSR managers playing a more active part in structuring the union network or establishing jointly led centralized monitoring. Following Dehnen and Pries (2014) and Sydow et al. (2014), our results confirm that, in practice, managerial and union approaches can be coordinated rather than simply juxtaposed. The micropolitics perspective allowed for understanding the adoption such coordinated practices, which were not initially adopted and were enacted in a second attempt in response to the internal difficulties of GUFs in coordinating union networks.

Third, our analysis illustrates the procedural nature of GFAs' dynamics. As seen just before, the adoption of coordinated monitoring mechanisms by Solvay, Danone or Carrefour is an answer to the observed difficulties of GUFs to coordinate the union network. The evolution of TNCs' policies toward GFAs can also depend on changes in the management side. The case of EDF is illustrative of this phenomenon. When the first GFA was signed in 2005, CSR was largely unconsidered by top management. There were no corporate policies or dedicated resources. The industrial relations manager who was in charge of CSR at the time perceived GFA as a way to legitimize the topic with other peripheral services. The topic gained importance, notably with the arrival of a new CEO in 2014 and was taken over by a structured, legitimate CSR department. The developed policy is now fully integrated in the managerial policy. When the GFA was renegotiated in 2017, the company had less interest in activating the union network. The negotiators turned to mobilization of the managerial channel rather than the structuration of the union network: "We really want to have balanced 
dual entry, that is, we really want management to commit and grab the issue. Not to exaggerate, but where there's no union, we want management to implement things."

Overall, our results support the micropolitics perspective and offer a better understanding of GFA and CSR in TNCs. They increase our understanding of why a company should opt for a GFA rather than a managerial approach such as a code of conduct. It also helps us understand the diversity in the methods of deployment of GFAs, i.e., the degree of coordination between the managerial and union channels. Most especially, it contributes to a better understanding of how GFAs implementation may interact with the political dynamics taking place in the management's side. Indeed, the literature on GFAs has widely highlighted the diversity of actors and the potential for dissent or even conflict within the labor's side. For example, Helfen and Fichter (2011) endeavored to capture the complexity of the heterogenous set of actors involved in transnational union networks by distinguishing several kinds of relationships, labeled to as labor-labor relations: first, the relationship between local/national and the transnational level and, second, the relationships between GUFs and internal representation bodies of employees and home country trade unions at the headquarter level. In a similar way, Dehnen (2013) focuses more specifically on the relationship between European Works Councils and GUFs with a theoretical perspective based on the internal and interorganizational negotiation model of Walter and McKersie (1965). In line with this twostep model of collective bargaining, Dehnen (2013) shows that internal bargaining between employee representation bodies determine which role and how much power the different bodies have in negotiations with management. Dehnen (2013) also shows how internal bargaining and bargaining between employee representation bodies and management mutually interact with each other. Conversely, although some few exceptions are to be noted (Egels-Zandén, 2009), the literature on IFAs has much less emphasized the complexity of the management's side. From this point of view, our study shows how the micropolitics perspective constitutes a useful theoretical framework in order to provide a better understanding of the ways GFAs negotiation and implementation processes also interact with complex political relationships within the management's side.

Another important issue that would deserve further investigation is how managerial actors ensure that signing a GFA will not act as a Trojan horse for other trade union demands. In a recent article, Mustchin and Martinez-Lucio (2017) show how transnational collective agreements can be used by trade unions as opportunities to enlarge their action and influence in the TNC. Taking the managerial point of view, we can imagine that such a risk is discussed 
between CSR managers and top management when deciding if it is suitable to negotiate with a GUF. This was evident in the cases studied and several CSR managers noted what they perceive as the misuse of the GFA, when the follow-up committee became a platform for demanding new rights. More generally, this raises the question of the compatibility between the partnership logic of GFAs and collective bargaining. If GUFs became threatening - e.g. by formulating excessive demands or threatening of public denunciation of company's dysfunctions -, the GFA could be cancelled. CSR or industrial relations departments often remind the GUFs how weak they are in the management side: "In case of difficulties, we told each other we would agree to not endanger our voluntary policy, which is not perfect, of course. But the enemies of this policy could exploit these difficulties for destabilizing us, me in the company, you in your trade-union". For this industrial relations director, the GFA implied solidarity between signatories, who must moderate their behavior as a result. Another industrial relations director stated: "I will be frank: if the negotiation becomes too tedious or if there are difficulties, I will remind them what a struggle it is for me to deal with CSR singlehandedly". For the GUFs, it is a challenge to coordinate the union network without echoing the local demands in collective bargaining.

Finally, our paper presents some intrinsic limitations that, at the same time, also offer opportunity for future research in order to scrutinize how GFAs are actually implemented at the local level and to assess the generalizability of our results across other geographical and institutional contexts. First, it was not within the scope of this article to study the local dynamics. As we aimed to explore the conjecture that GFAs act as an alliance between CSR managers and trade unions at the headquarters level of TNCs, we only conducted interviews at the central level. Nevertheless, it would be useful to extend these observations to the local level to understand how local actors approach the trade-off between local arrangements and cooperation with upper levels. It is particularly important to understand the intra-union relationships because, as revealed by our results, most CSR managers appear to overestimate the convergence of interests within the union network.

Second, in this study we chose to reduce the observation to a unique national context to control for the country-of-origin effect that is highlighted in the literature (for example, Tempel et al. 2006). Although the theoretical framework we developed could function in other countries, it remains to be tested. The French industrial relations system is characterized by national coordination with strong interprofessional and sectoral dimensions. French trade unions are more accustomed to multilevel cooperation than trade unions in other countries 
such as North America, where industrial relations are organized at the workplace level. This could explain the statistical overrepresentation of countries such as France, Germany or Sweden in the signed GFAs. At a theoretical level, this shows that it will be useful to explore the articulation of institutional and micropolitics dimensions as initiated by Helfen et al. (2016).

\section{Funding:}

This study was funded by the Paris office of the International Labour Organization.

\section{Compliance with Ethical Standards:}

Conflict of interest Rémi Bourguignon, Pierre Garaudel and Simon Porcher declare that they have no conflict of interest.

Ethical approval. All procedures performed in studies involving human participants were in accordance with the ethical standards of the institutional and national research committee and with the 1964 Helsinki declaration and its later amendments or comparable ethical standards.

Informed consent. Informed consent was obtained from all individual participants included in the study

\section{References}

Barnes, D. M. (1996). An analysis of the grounded theory method and the concept of culture. Qualitative Health Research, 6, 429-441.

Bouquet, C., \& Birkinshaw, J. (2008). Weight versus voice: How foreign subsidiaries gain attention from corporate headquarters. Academy of Management journal, 51(3), 577-601.

Burns, T. (1961). Micropolitics: Mechanisms of institutional change. Administrative Science Quarterly, 6, 257-281.

Chamberlain, N. W., \& Kuhn, J. W. (1965). Collective bargaining. New York: McGraw-Hill Dehnen, V. (2013). Transnational Alliances for Negotiating International Framework Agreements: Power Relations and Bargaining Processes between Global Union Federations and European Works Councils. British Journal of Industrial Relations, 51(3), 577-600. 
Dehnen, V., \& Pries, L. (2014). International Framework Agreements: A thread in the web of transnational labour regulation. European Journal of Industrial Relations, 20(4), 335-350.

Donaghey, J., \& Reinecke, J. (2018). When Industrial Democracy Meets Corporate Social Responsibility-A Comparison of the Bangladesh Accord and Alliance as Responses to the Rana Plaza Disaster. British Journal of Industrial Relations, 56(1), 14-42.

Dörrenbächer, C., \& Geppert, M. (2006). Micro-politics and conflicts in multinational corporations: Current debates, re-framing, and contributions of this special issue, Journal of International Management 12 (3), 251-265.

Egels-Zandén, N. (2009). TNC motives for signing international framework agreements: A continuous bargaining model of stakeholder pressure. Journal of Business Ethics, 84(4), 529547.

Egels-Zandén, N., \& Hyllman, P. (2007). Evaluating strategies for negotiating workers' rights in transnational corporations: The effects of codes of conduct and global agreements on workplace democracy. Journal of Business Ethics, 76(2), 207-223.

Egels-Zandén, N., \& Merk, J. (2014). Private regulation and trade union rights: Why codes of conduct have limited impact on trade union rights. Journal of Business Ethics, 123(3), 461473.

Eisenhardt, K. M. (1989). Building theories from case study research. Academy of management review, 14(4), 532-550.

Fichter, M., Helfen, M., \& Sydow, J. (2011). Employment relations in global production networks: Initiating transfer of practices via union involvement. Human Relations, 64(4), 599622.

Fichter, M., \& McCallum, J. K. (2015). Implementing global framework agreements: The limits of social partnership. Global Networks, 15(1), 65-85.

Hadwiger, F. (2015) Global framework agreements: achieving decent work in global supply chains? International Journal of Labour Research, 7(1), 75-94.

Helfen, M., \& Fichter, M. (2011, January). Global production networks and global union federations: Re-assembling transnational union networks by International Framework Agreements?. In Global Labour University Conference, At Johannesburg, South Africa. 
Helfen, M., \& Fichter, M. (2013). Building transnational union networks across global production networks: Conceptualising a new arena of labour-management relations. British Journal of Industrial Relations, 51(3), 553-576.

Helfen, M. O., Schüßler, E., \& Stevis, D. (2016). Translating European Labor Relations Practices to the United States Through Global Framework Agreements? German and Swedish Multinationals Compared. ILR Review, 69(3), 631-655.

International Labour Organization (ILO). (2016). Report IV. Decent work in global supply chains. Geneva: International Labour Organization, 105th Session.

Karlberg, E., \& Jacobsson, K. (2015). A Meta-organizational Perspective on the Europeanization of Civil Society: The Case of the Swedish Women's Lobby. VOLUNTAS: International Journal of Voluntary and Nonprofit Organizations, 26(4), 1438-1459.

Kristensen, P. H., \& Zeitlin, J. (2005). Local players in global games: The strategic constitution of a multinational corporation. Oxford University Press.

Lawrence, P. R., \& Lorsch, J. W. (1967). Differentiation and integration in complex organizations. Adminis trative science quarterly, 1-47.

Lévesque, C., Bensusán, G., Murray, G., Novick, M., Carrillo, J., \& Gurrera, M. S. (2015). Labour relations policies in multinational companies: A three-country study of power dynamics. Journal of Industrial Relations, 57(2), 187-209.

Lévesque, C., Hennebert, M. A., Murray, G., \& Bourque, R. (2016). Corporate Social Responsibility and Worker Rights: Institutionalizing Social Dialogue Through International Framework Agreements. Journal of Business Ethics, 1-16.

Lund-Thomsen, P. \& Lindgreen A., (2014) A. Corporate social responsibility in global value chains: where are we now and where are we going?, Journal of Business Ethics, 123(1), 1122.

Mustchin, S., \& Martinez-Lucio, M. (2017). Transnational Collective Agreements and the Development of New Spaces for Union Action: The Formal and Informal Uses of International and European Framework Agreements in the UK. British Journal of Industrial Relations, 55(3), 577-601. 
Niforou, C. (2012). International framework agreements and industrial relations governance: Global rhetoric versus local realities. British Journal of Industrial Relations, 50(2), 352-373.

Niforou, C. (2014). International framework agreements and the democratic deficit of global labour governance. Economic and Industrial Democracy, 35(2), 367-386.

Papadakis, K., ed., (2008). Cross-border social dialogue and agreements. An Emerging Global Industrial Relations Framework. International Institute for Labour Studies: Geneva.

Saldaña, J. (2013). The coding manual for qualitative researchers. London: Sage.

Sydow, J., Fichter, M., Helfen, M., Sayim, K. Z., \& Stevis, D. (2014). Implementation of Global Framework Agreements: towards a multi-organizational practice perspective. Transfer: European Review of Labour and Research, 20(4), 489-503.

Tempel, A., Edwards, T., Ferner, A., Muller-Camen, M., \& Wächter, H. (2006). Subsidiary responses to institutional duality: Collective representation practices of US multinationals in Britain and Germany. Human Relations, 59(11), 1543-1570.

Wickert, C., \& de Bakker, F. G. (2015). Managerial struggles during practice implementation: The case of corporate social responsibility. In Academy of Management Proceedings, Vol. 2015, No.1, p.10912.

Williams, G., Davies, S., \& Chinguno, C. (2015). Subcontracting and labour standards: Reassessing the potential of international framework agreements. British Journal of Industrial Relations, 53(2), 181-203.

Walton, R. E., \& McKersie, R. B. (1965). A behavioral theory of labor negotiations: An analysis of a social interaction system. Cornell University Press.Wills, J. (2002). Bargaining for the space to organize in the global economy: a review of the Accor-IUF trade union rights agreement. Review of International Political Economy, 9(4), 675-700. 